\title{
Evolving and Enduring Patterns Surrounding Student Usage and Perceptions of Academic Library Reference Services
}

\author{
Jodi Jameson, Gerald Natal, and John Napp
}

\begin{abstract}
This descriptive study analyzes results from an 18-item survey that assessed students' usage and perceptions of library reference services at a comprehensive public metropolitan university. Among 235 surveys completed between November 2016 and January 2017, the majority of respondents represented the "Generation Z" population of college students, 18 to 24 years of age. Quantitative and qualitative findings revealed patterns of reference service usage, perceptions of librarians, and barriers and facilitators to seeking help from a librarian. These findings can inform decision making to improve marketing and outreach to students regarding general reference services, reference models, and liaison roles.
\end{abstract}

\section{Introduction}

Exemplary reference service is a natural goal for any academic librarian. Yet, regardless of efforts by librarians to provide optimal service, there are always students who do not take advantage of a librarian's expertise and enthusiasm to provide assistance. Librarians at The University of Toledo (UT), investigating new reference models in light of shrinking personnel and a library reorganization, became curious about the use of their reference services across a wide spectrum of students from the humanities to the STEMM (Science, Technology, Engineering, Mathematics, and Medicine) disciplines. The authors, three faculty librarians at UT (liaisons for engineering, health and human services, and nursing) developed and distributed a survey to UT students with the aim of answering the following research questions:

- Are there differences in characteristics among students who do or do not use library reference services?

- What are students' perceptions of reference librarians' identities and approachability?

- What are students' perceived barriers and facilitators to seeking reference assistance from a librarian?

Survey respondents represented every degree-granting college at UT, except for students in the College of Law whose library is separate from the UT Libraries organizational structure.

Jodi Jameson is Assistant Professor, Nursing Librarian, and Gerald Natal is Assistant Professor, Health and Human Services Librarian, both in the Mulford Health Science Library, and John Napp is Associate Professor, Engineering Librarian, in the Carlson Library, all at The University of Toledo; email: jodi.jameson@utoledo.edu, gerald.natal@utoledo.edu, john.napp@utoledo.edu.@2019 Jodi Jameson, Gerald Natal, and John Napp, AttributionNonCommercial (http://creativecommons.org/licenses/by-nc/4.0/) CC BY-NC. 
Additionally, the survey included students from the UT Health Science Campus, which provided a range and scope not common in the literature. Therefore, the results are potentially applicable to student populations for a wide range of institutions.

\section{Background}

Established in 1872, UT is a comprehensive public metropolitan research university located in Toledo, Ohio. With an enrollment of more than 20,000 students, UT consists of a Main Campus and Health Science Campus. Carlson Library, located on the Main Campus, is the largest library at UT, serving a wide variety of users including traditional, first-year undergraduate students. On the Health Science Campus, the Mulford Library serves students, faculty, and staff in medicine, nursing, and pharmacy, as well as clinical faculty and staff at The University of Toledo Medical Center. At the time of this survey, the McMaster Engineering Library was located in an engineering classroom building on Main Campus. In June 2017, this library closed due to an administrative decision to centralize the Engineering Librarian's services at Carlson Library.

Hybrid, tiered reference models exist at the UT Libraries to meet students' research and information needs. At Carlson Library, a reference desk is staffed primarily by part-time reference assistants and students, with librarians on call to answer higher-level questions. The Mulford Library uses an on-call reference model, wherein questions are fielded by staff at the service desk and referred to the scheduled on-call librarian. During the time that the Engineering Library was in operation, it also used on an on-call reference model with fielded questions referred by student workers to the Engineering Librarian. All UT reference librarians also monitor the reference telephone, email, and online chat service during scheduled hours. In addition, reference librarians serve as subject liaisons to academic departments and colleges at the university, teach course-integrated information literacy instruction sessions, conduct scheduled individual and small-group research consultations, and participate in collection development activities.

\section{Selective Review of the Literature}

Fostering positive relationships with patrons is a long-standing concern for librarians. In an article published in 1876, Samuel S. Green offered insight into patron types and the importance of good rapport with patrons, and he provided guidelines for delivering quality reference service to "readers" (as he called them). ${ }^{1}$ However, assessment of library services was largely concentrated on collections until the 1970s, during which evaluation of reference services gained importance. ${ }^{2}$ Emphasis remained on evaluating reference transactions until studies like those done by Hernon and Pastine began to explore reference services from patrons' points of view. ${ }^{3}$ Yet gathering accurate and complete data about reference effectiveness from patrons' perspectives remained a challenge. Therefore, in the 1980s, Murfin, Gugelchuk, and Bunge developed the valid and reliable WOREP (Wisconsin-Ohio Reference Evaluation Program) instrument with the aim of standardizing user assessment, eliminating response bias, and measuring satisfaction and success as separate outcomes of the reference encounter. ${ }^{4}$ This tool has been deemed useful for improving training and reference services, developing new models of reference, and building specialized (music reference) services. ${ }^{5}$

Students previously surveyed in the literature have frequently expressed feelings of insecurity, embarrassment, or concern about interrupting librarians for help with research. These and similar concerns appear throughout the literature and have been placed under the 
umbrella term "library anxiety." ${ }^{6}$ Over the years, studies have used or adapted the Library Anxiety Scale created by Bostick to measure a multitude of factors that affect students' ability to seek assistance from library personnel. ${ }^{7}$ These studies focused on library anxiety in relation to other classifications of anxiety, defining the traits of anxious students, the relationship between library instruction and anxiety, and the measurement of anxiety. ${ }^{8}$ Martin and Park suggest that requiring mandatory meetings with librarians reduces anxiety by minimizing the stress of the initial approach for assistance. ${ }^{9}$ Library instruction has also been recommended as an intervention to prevent at-risk college students from developing library anxiety, and it has been shown to reduce students' library anxiety levels. ${ }^{10}$ The literature overwhelmingly promotes positive interaction between students and librarians, together with attention to the library environment, to diminish library anxiety. ${ }^{11}$ Personalization of reference services, including familiarity with a liaison or subject librarian, has been suggested as a factor that encourages students to consult with a librarian rather than with other students or the course instructor. ${ }^{12}$ Diversity among personnel at the reference desk may also contribute to a more comfortable user environment. ${ }^{13}$

DeVore-Chew, Roberts, and Smith concentrated their research on nonverbal cues such as distance, facial expression, and physical contact during the reference transaction. ${ }^{14}$ The authors found no significant relationship, although they admit inconsistencies among studies of this type. A decade later, Radford - using unobtrusive observation and interview methodology - found that there was a positive relationship between nonverbal cues and the reference transaction. Also telling were the effects of demographics on the use of library services. ${ }^{15} \mathrm{~A}$ study by Bonnet and McAlexander in 2012 used a survey and approachability rating scale to determine that age, race, and gender all play a significant role in users' perceptions of library reference services. ${ }^{16}$ Ismail concentrated on the help-seeking habits of distance-learning students by age. While there was some variance by age regarding the frequency of asking for assistance, generally, across the spectrum, distance students only sought help when desperately needed; instructors were consulted first, and librarians were a last resort. ${ }^{17}$

Another demographic research approach is analysis by generation. Gardner and Eng chose to study Generation Y, the Millennials (born between 1980 to the mid-1990s). The students surveyed did not think of the library as a physical space; they preferred researching online. This study concluded that web use has created an "ATM attitude" of expediency and confidence, thereby lessening the likelihood that students will ask a librarian for assistance. ${ }^{18}$ More recently, the book Generation Z Goes to College explores the habits of the generation born between 1995 and 2010. Behavior of the group studied for the book shows that, like Millennials, access to information and physical boundaries are not issues. Survey results found that 83 percent of Generation Z students still favor face-to-face communication, yet inconsistently they also prefer to learn independently; they have no problem seeking counsel from their peers, and they rely exceedingly on text messaging. ${ }^{19}$ Any of these factors could influence use of library reference services. The research of Xie and Sun is a reminder that common reference usage patterns exist outside Western culture as well. Surveyed Chinese students revealed that they felt confident enough to conduct research on their own, rendering the available reference services underused. This was attributed to increased web use, a teacher-centric approach to instruction (mostly in-class), and reference services in need of improvement and promotion. ${ }^{20}$

Black and Krawczyk administered two short interventions in the form of narratives to test whether these would have positive effects on students' willingness to meet with librarians. A 
group of students received narratives describing positive interactions with librarians and attempts to develop good research skills; a control group received only facts concerning the library. The narratives did not have a positive effect on students' attitudes toward library research, which the authors attributed to an increased awareness by the students of the amount of work involved in the research process. One finding that runs counter to existing literature is that this particular group of students was not concerned with negative peer judgment if they asked a librarian for assistance. ${ }^{21}$ A further look at peer relationships in the library applies to student reference workers, who may be more understanding of student needs, are apt to be more approachable, and can positively influence student perceptions of reference services. ${ }^{22}$ Moreover, some students profess to a greater feeling of comfort when dealing with peers. ${ }^{23}$ This brings up the question of identity, as many students are unable to differentiate from among the individuals sitting behind the reference desk. ${ }^{24}$ Students may be unaware of librarians' educational backgrounds and status as professionals and may not equate library instruction with teaching. ${ }^{25}$

A reduced use of professional librarians' reference services need not be entirely due to negative perceptions of libraries or librarians, or a lack of knowledge about librarians' backgrounds and duties. The use of student reference workers, successful library instruction sessions, and replacing the traditional reference desk model for an appointment approach may be alternative explanations. ${ }^{26}$ On a more philosophical note, Harley, Dreger, and Knobloch commented on the role of postmodern thinking in shaping student perceptions. Postmodernist notions of relevant truth, consumerism, and subjective thinking make researching on the web a preferred method for many students, contributing to fewer visits to the reference desk. ${ }^{27}$

\section{Methodology}

\section{Data Collection}

This study implemented a descriptive survey design. An 18-item survey instrument consisting of closed and open-ended questions was developed to collect quantitative and qualitative data about current UT students' usage and perceptions of library reference services (see appendix). Survey questions were designed to gather information on basic demographic data, the nature and frequency of students' reference service usage, students' perceptions of librarians, and barriers and facilitators to asking librarians for help. In an effort to test the relationship between library instruction and reference service usage, the survey included questions regarding students' receipt of classroom library instruction and professor mandates to consult with a librarian.

Following IRB approval, the survey was made available to students during a three-month period from November 2016 through January 2017. The nonprobability sampling method of self-selection was used. Students were invited to complete the survey either online (in SurveyMonkey) or in paper form. The survey was promoted a variety of ways. Information about the survey was forwarded by library liaisons to college administrative support staff, who in turn emailed the survey information to students en masse. Also, a link to the online survey was placed on the UT Libraries website. In addition, the survey was promoted via UT Libraries social media pages, including Facebook and Twitter. In an effort to reach distance learning students, a link to the online survey was placed on the Blackboard landing page by the UT Online instructional design team at the request of the authors. Kiosks were set up in the Carlson, Mulford, and Engineering libraries where students could complete and submit the paper form of the survey. In total, 236 surveys were submitted by individual respondents. One survey was discarded by the authors due to its obviously facetious responses. 


\section{Data Analysis}

Responses from 235 surveys were analyzed for this study. The majority of respondents completed the survey online in SurveyMonkey $(86 \%, n=202)$, while a smaller number completed the survey in paper form $(14 \%, \mathrm{n}=33)$. Responses from paper surveys were manually entered into SurveyMonkey to streamline the process of analysis. SurveyMonkey's built-in data analysis tools were used to generate frequency statistics. Data was imported into SPSS 24 for additional descriptive statistical analysis using cross-tabulations. SPSS 24 was also used to manage responses from Question \#5: "What college/school/program are you enrolled in?" Value labels were created and assigned to individual responses from this question to facilitate analysis of data by college (for example, responses such as "Medical School" or "MD Program" were assigned the value label College of Medicine and Life Sciences). Qualitative responses from open-ended questions were analyzed using Gibbs's method of thematic coding and categorizing. ${ }^{28}$ Open-ended responses were read and reread for words, phrases, or ideas that signified common meanings. Textual passages from open-ended responses were then coded to corresponding themes using the My Categories function in SurveyMonkey, a process outlined by Vaughn and Turner. ${ }^{29}$

\section{Quantitative Results \\ Demographics}

Table 1 provides a list of respondents' demographic characteristics. The majority of respondents were 18 to 24 years of age, undergraduate, female, and Caucasian. Students in the College of Engineering formed the largest discipline-specific respondent group, followed by students in the College of Arts and Letters (representing the humanities, visual arts, interdisciplinary studies, preprofessional programs, and social sciences). Nearly three-fourths of overall respondents were students in science, technology, health sciences, and human services disciplines, representing the colleges of Engineering, Nursing, Medicine and Life Sciences, Health and Human Services, Natural Sciences and Mathematics, and Pharmacy and Pharmaceutical Sciences. Students in the colleges of Business and Innovation and Education comprised a smaller portion of respondents, as did students in University College, which provides interdisciplinary and special programs designed for individual learners' needs. A small number of respondents were categorized as "Other," including those who responded with generic, nonspecific answers such as "University of Toledo" or "N/A."

\begin{tabular}{|l|c|c|l|c|c|}
\hline \multicolumn{7}{|c|}{ TABLE 1 } \\
\hline Demographic Profile of Survey Respondents \\
\hline Characteristics & $\mathbf{n}$ & $\mathbf{\%}$ & Characteristics & $\mathbf{n}$ & $\mathbf{\%}$ \\
\hline $\mathbf{1 8 - 2 4}$ & & & Gender & & \\
\hline $25-34$ & $\mathbf{1 8 0}$ & $\mathbf{7 7}$ & Female & $\mathbf{1 4 7}$ & $\mathbf{6 3}$ \\
\hline $35-44$ & 35 & 15 & Male & 86 & 37 \\
\hline $45-54$ & 8 & 3 & Preferred not to answer & 2 & 1 \\
\hline 55 or older & 8 & 3 & & & \\
\hline
\end{tabular}




\begin{tabular}{|l|c|c|l|c|c|}
\hline \multicolumn{5}{|c|}{ TABLE 1 } \\
\hline \multicolumn{5}{|c|}{ Demographic Profile of Survey Respondents } \\
\hline Characteristics & $\mathbf{n}$ & $\mathbf{\%}$ & Characteristics & $\mathbf{n}$ & $\%$ \\
\hline Race/Ethnicity & & & College & 44 & 19 \\
\hline African & 8 & 3 & Arts and Letters & 10 & 4 \\
\hline African-American & 20 & 9 & Business and Innovation & 5 & 2 \\
\hline Asian & 11 & 5 & Education & $\mathbf{6 7}$ & $\mathbf{2 9}$ \\
\hline Asian-American & 4 & 2 & Engineering & 23 & 10 \\
\hline Caucasian & $\mathbf{1 7 7}$ & $\mathbf{7 6}$ & Health and Human Services & 24 & 10 \\
\hline Latino/Hispanic & 11 & 5 & Medicine and Life Sciences & 6 & 3 \\
\hline Latino/Hispanic-American & 5 & 2 & Natural Sciences and Mathematics & 38 & 16 \\
\hline Middle Eastern & 10 & 4 & Nursing & 7 \\
\hline Native American & 4 & 2 & Pharmacy and Pharmaceutical Sciences & 7 \\
\hline Pacific Islander & 2 & 1 & University College & 5 & 2 \\
\hline Mixed Race/Other & 16 & 7 & Other & 6 & 3 \\
\hline Student Status* & & & & & \\
\hline Undergraduate & $\mathbf{1 7 3}$ & $\mathbf{7 4}$ & & & \\
\hline Graduate & 57 & 24 & & & \\
\hline Distance Learner & 6 & 3 & & & \\
\hline New Student & 19 & 8 & & \\
\hline International Student & 6 & 3 & & \\
\hline Transfer Student & 16 & 7 & & \\
\hline Military Veteran & 3 & 1 & & \\
\hline $\begin{array}{l}\text { Percentages may not add up to } 100 \% \text { due to rounding. } \\
\text { *Respondents were permitted to select more than one answer. }\end{array}$ & \\
\hline
\end{tabular}

\section{Students' Usage and Nonusage of Library Reference Services}

The majority of survey respondents indicated that they often physically visited a UT campus library (see table 2). Yet, in response to the question, "How often have you asked a librarian for help?" nearly half of respondents indicated "Never" (see figure 1).

\begin{tabular}{|c|c|c|}
\hline \multicolumn{3}{|c|}{$\begin{array}{c}\text { TABLE } 2 \\
\text { Library Visited Most Often } \\
\text { (Total Respondents = 233) }\end{array}$} \\
\hline & $\mathbf{n}$ & $\%$ \\
\hline Carlson (Main Campus) & 182 & 78 \\
\hline Mulford (Health Science Campus) & 37 & 16 \\
\hline McMaster (Engineering) & 4 & 2 \\
\hline LaValley (Law) & $1 *$ & 0.4 \\
\hline I have not visited the library & 9 & 4 \\
\hline \multicolumn{3}{|c|}{$\begin{array}{l}\text { Percentages may not add up to } 100 \% \text { due to rounding } \\
\text { *The Law Library is open to any UT student for study; } \\
\text { this respondent was a non-College of Law student. }\end{array}$} \\
\hline
\end{tabular}

Students' most frequent reason selected for not seeking help from a librarian (see figure 2) was "I like to figure things out on my own." The majority of students who selected this answer were undergraduates $(79 \%, \mathrm{n}=54)$ and 18 to 24 years of age $(82 \%$, $\mathrm{n}=56)$. Slightly over half $(54 \%, \mathrm{n}=37)$ were students who responded " $\mathrm{No}^{\text {" when asked }}$ if a librarian had visited their classroom to provide instruction. Several respondents also provided an open-ended answer for the "Other" category, with the majority stating that the reason they never sought 


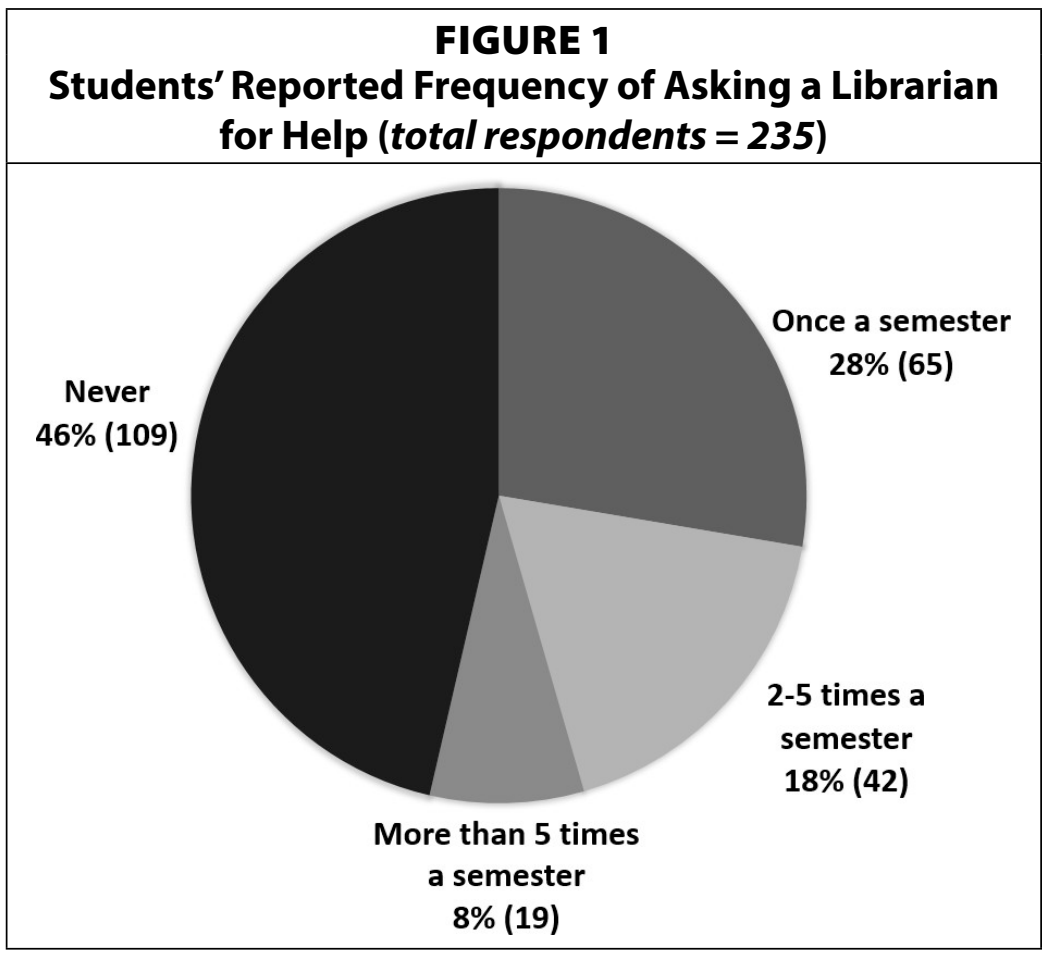

help from a librarian was because they did not have a need.

Although a sizable portion of respondents indicated that they had never asked a librarian for help, slightly more than half $(\mathrm{n}=$ 126) of overall respondents indicated that they had asked for help from a librarian at least once a semester (see figure 1). The authors became interested in whether certain factors and characteristics correlated to survey respondents' frequency of asking a librarian for help (see table 3).

One pertinent finding was that, among the 57 graduate students who responded to the survey, the majority $(74 \%, \mathrm{n}=42)$ had asked for help at least once a semester. Filtering by college revealed that 86 percent of these 42 graduate students were in professional programs including medicine $(n=16)$, nursing $(n=8)$, engineering $(n=7)$, and health and human services $(n=5)$. Cross-tabulation was performed to compare the relationship between students' frequency levels of seeking help and whether or not those students

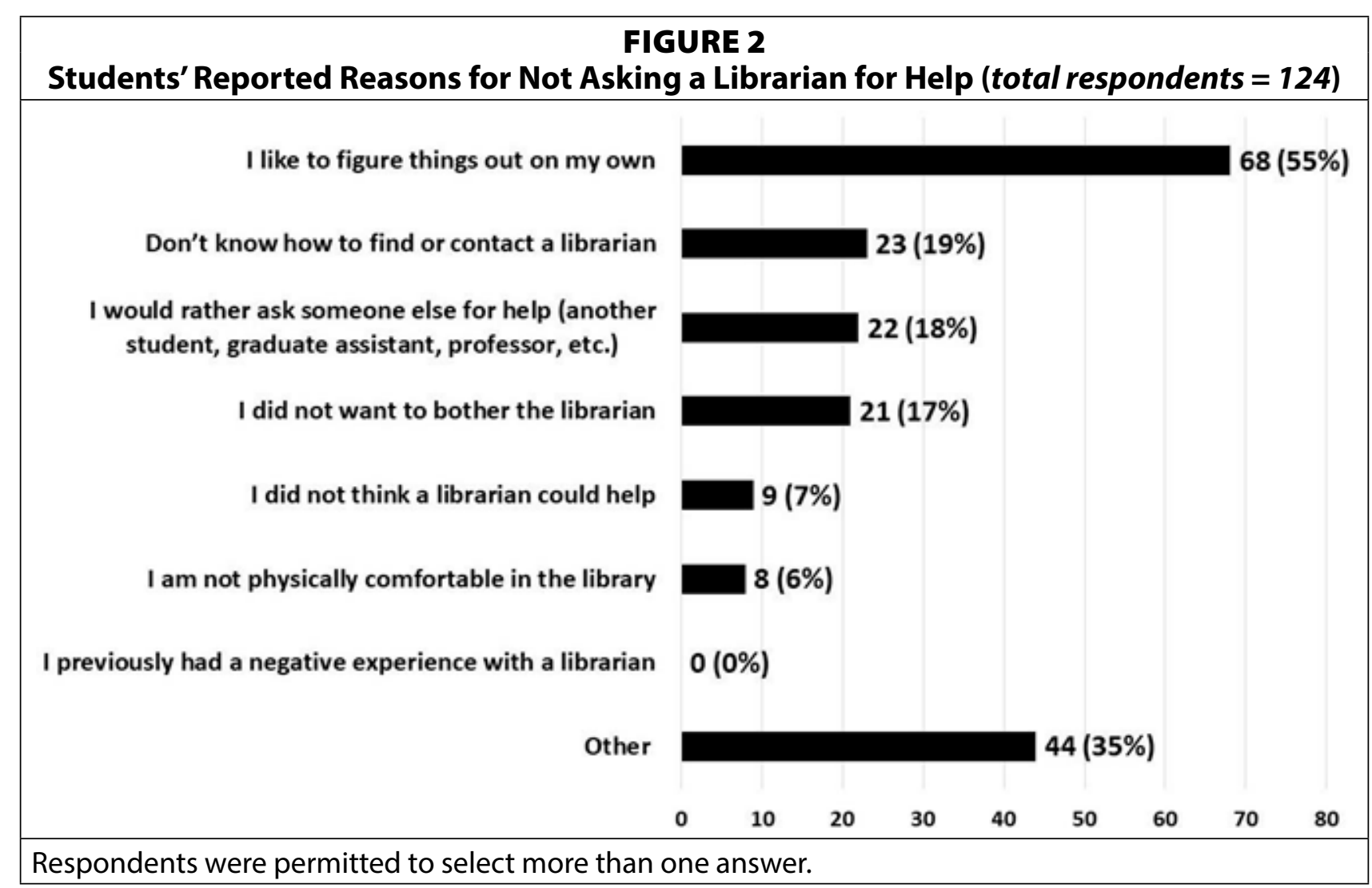


had received library instruction. Across all three frequency categories of asking a librarian for help (either once a semester, 2-5 times a semester, or more than 5 times a semester), a greater percentage of respondents in each of these three categories was among those who reported not receiving library instruction. Yet, among respondents who had never asked for help, a greater portion was also that group of students who had not received library instruction.

Survey data also provided information regarding why and how students sought help from librarians (see figure 3). Respondents' top reason for seeking help from a librarian was "To learn how to use a library resource." A small percentage of respondents indicated that they had sought help from a librarian "To get help with citations/reference lists," with the majority being graduate students $(n=12)$. Students listed additional reasons for seeking help under "Other," including directional and technology-related information needs.

\begin{tabular}{|c|c|c|c|c|}
\hline Students' Reporte & d Frequency of & $\begin{array}{c}\text { TABLE } 3 \\
\text { sking a Libraria }\end{array}$ & Help by Selected Ch & teristics \\
\hline Characteristics & $\begin{array}{c}\text { Once a } \\
\text { semester } n(\%)\end{array}$ & $\begin{array}{c}\text { 2-5 times a } \\
\text { semester } \mathbf{n}(\%)\end{array}$ & $\begin{array}{c}\text { More than } 5 \text { times a } \\
\text { semester } \mathbf{n}(\%)\end{array}$ & $\begin{array}{c}\text { Never } \\
\text { n (\%) } \\
\end{array}$ \\
\hline Age Group & & & & \\
\hline $18-24$ & $53(82)$ & $25(60)$ & $11(58)$ & $91(83)$ \\
\hline $25-34$ & $10(15)$ & $9(21)$ & $5(26)$ & $11(10)$ \\
\hline $35-44$ & $1(2)$ & $3(7)$ & 一 & $4(4)$ \\
\hline $45-54$ & $1(2)$ & $3(7)$ & $1(5)$ & $3(3)$ \\
\hline 55 or older & - & $2(5)$ & $2(10)$ & - \\
\hline Total Respondents & 65 & 42 & 19 & 109 \\
\hline Student Status* & & & & \\
\hline Undergraduate & $46(70)$ & $29(70)$ & $11(58)$ & $87(80)$ \\
\hline Graduate & $22(34)$ & $13(31)$ & $7(37)$ & $15(14)$ \\
\hline Distance Learner & $1(2)$ & $1(2)$ & - & $4(4)$ \\
\hline International Student & $2(3)$ & $1(2)$ & - & $3(3)$ \\
\hline Military Veteran & $1(2)$ & - & $1(5)$ & $1(0.9)$ \\
\hline New Student & $3(5)$ & $5(12)$ & $1(5)$ & $10(9)$ \\
\hline Transfer Student & $5(8)$ & $2(5)$ & $1(5)$ & $8(7)$ \\
\hline Total Respondents & 65 & 42 & 19 & 109 \\
\hline Received Classroom & -ibrary Instructic & & & \\
\hline Yes & $22(35)$ & $12(29)$ & $4(21)$ & $32(30)$ \\
\hline No & $32(51)$ & $25(60)$ & $15(79)$ & $66(61)$ \\
\hline Don't remember & $9(14)$ & $5(12)$ & - & $10(9)$ \\
\hline Total Respondents & 63 & 42 & 19 & 108 \\
\hline Required by Professo & r to Consult with & ibrarian ${ }^{\dagger}$ & & \\
\hline Yes & $10(16)$ & $10(24)$ & $3(16)$ & $4(4)$ \\
\hline No & $53(84)$ & $32(77)$ & $16(84)$ & $104(96)$ \\
\hline Total Respondents & 63 & 42 & 19 & 108 \\
\hline $\begin{array}{l}\text { Percentages may not } \\
\text { *Respondents were } \mathrm{p} \\
\text { 'Some respondents di }\end{array}$ & $\begin{array}{l}\text { Id up to } 100 \% \mathrm{~d} \\
\text { mitted to select } \\
\text { not answer que }\end{array}$ & $\begin{array}{l}\text { o rounding. } \\
\text { re than one ans } \\
\text { n. }\end{array}$ & & \\
\hline
\end{tabular}




\section{FIGURE 3}

\section{Students' Reported Reasons for Asking a Librarian for Help (total respondents = 126)}

To learn how to use a library resource (catalog, database, software, online book, etc.)

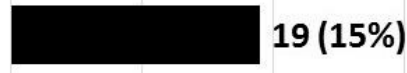

Other

0

10

20

30

40

50

60

70

Respondents were permitted to select more than one answer.

When students were asked how they had interacted with a librarian, the most popular mode of communication among respondents $(n=151)$ was "In person" $(87 \%, n=132)$ followed by "Email" (19\%, n = 29), "Chat/instant messaging" (9\%, n = 14) and "Telephone" (7\%, n = 11). Some respondents chose the "Other" category $(8 \%, \mathrm{n}=12)$, with nearly all indicating that they had no need to contact a librarian. Two students stated that, if they did need help, they would prefer do so in person. A distance learner stated that they felt intimidated to contact a librarian online.

Students were also queried whether they had asked someone else for help prior to speaking with a librarian. Of the 122 respondents who chose to answer this question, most indicated that they had asked a "Friend" first $(52 \%, \mathrm{n}=64)$, followed by a "Student from my class" (38\%, $\mathrm{n}=46)$, "Professor/Instructor" $(38 \%, \mathrm{n}=46)$, and "Family member" $(10 \%, \mathrm{n}=12)$. Among the 20 respondents who chose the "Other" category (16\%), most responded with answers such as "No" or "N/A," while two respondents indicated that they had asked for help first from a "Business Associate" and "Success Coach."

\section{Student Perceptions of Librarians}

Students were also asked questions about their ability to identify librarians and their ratings of librarians' approachability. A total of 223 students responded to the question, "When visiting the library, can you tell which library workers are librarians?" Among these respondents, 38 percent $(n=85)$ chose this answer: "I can't tell which library workers are librarians." Other respondents identified librarians as being located in a public service desk position. Twenty-seven percent $(n=61)$ chose the answer "Anyone behind the reference desk," while 26 percent $(n=$ 57) responded "Anyone behind the circulation (checkout) desk." A small portion of respondents $(5 \%, \mathrm{n}=12)$ chose this answer: "Only the people with library degrees are librarians." 
Of the 85 students who could not identify librarians, the majority $(59 \%, n=50)$ were among those who stated that they had never asked a librarian for help. Also, the majority of these 85 students were among those who responded " $\mathrm{No}^{\prime}(58 \%, \mathrm{n}=49)$ when asked if a librarian visited their classroom to provide instruction. Eighty-seven percent $(n=74)$ of students who could not identify librarians also responded " $\mathrm{No}^{\prime}$ when asked if they were ever required by a professor to consult with a librarian.

Overall, quantitative findings revealed that students held favorable views of librarians' approachability. Of the 228 students who responded to the question, "In general, how would you rate the approachability of librarians at UT (online or in person)?" 46 percent rated librarians as "Approachable" ( $n=105)$, followed by "Very approachable" (33\%, $n=75)$ and "Slightly approachable" (16\%, n=37). However, many respondents to the previously discussed question indicated that they could not identify librarians. Therefore, these approachability ratings may imply that respondents perceive all library workers in general to be approachable.

Only 5 percent $(n=11)$ of respondents rated librarians as "Not at all approachable." All 11 students who viewed librarians as unapproachable also responded that a professor had not required them to consult with a librarian. Also, 9 of these 11 respondents were students who had never received library instruction and had never asked a librarian for help. Seven of these 11 respondents also responded that they could not tell which library workers were librarians.

\section{Qualitative Results}

To triangulate data received from quantitative responses, the authors also asked two openended questions to gather qualitative data on students' perceived barriers and facilitators to seeking help from a librarian. Several themes emerged from the qualitative data analysis, summarized below with exemplary quotes. Outlying responses, such as "Not applicable" or "N/A," were not included in the qualitative analysis. Some individual responses were coded to more than one theme (for example, if a respondent began articulating an inability to identify librarians, but then transitioned into describing feelings of library anxiety).

\section{Barriers to Seeking Help from Librarians}

Ninety-five percent $(n=224)$ of survey respondents answered this question: "What makes it difficult for you to ask a librarian for help?" Many students felt that there were no barriers. The most prevalent theme that emerged from students' responses was that nothing $(\mathrm{n}=$ 68) made it difficult to ask a librarian for help. Several of these respondents provided short answers such as "Nothing" or "not difficult." Other students offered explanations regarding why it was not difficult to ask a librarian for help. A graduate student commented on librarians' approachability and expertise as factors in enabling them to ask for help: "Nothing - the librarians are always warm, friendly, and knowledgeable!" Awareness of librarians' job roles was described as a factor in facilitating this undergraduate student's help-seeking behavior: "I don't find it difficult to ask for help because that is part of their job."

While many students felt it was not difficult to ask a librarian for help, several others also indicated that they had no need to seek a librarian's assistance $(n=48)$. Some students described feelings of self-sufficiency, rendering the need to seek help unnecessary, as indicated by this graduate student's response: "Generally not necessary; I'm generally a self-sustaining person when it comes to figuring out what I need and how to obtain it." Another graduate student provided insightful reflection on this theme: "I think we live in a world where a lot of information is only a 
click away. We are conditioned to seek out answers ourselves on Google or other sites. People in general don't know the extent of resources the library provides and this combined with the expectation to be self-sufficient might explain a patron's reluctancy [sic] to ask for help."

\begin{tabular}{|c|c|c|}
\hline \multicolumn{3}{|c|}{$\begin{array}{l}\text { TABLE } 4 \\
\text { Barriers and Facilitators to Asking a Librarian for Help }\end{array}$} \\
\hline \multirow[t]{7}{*}{ Barriers } & Themes & Frequency of Theme \\
\hline & - Inability to identify librarians & 31 \\
\hline & - Library anxiety & 25 \\
\hline & - Lack of awareness & 15 \\
\hline & - Librarian unapproachability & 12 \\
\hline & - Inconvenience & 12 \\
\hline & - Lack of confidence in librarians' abilities & 5 \\
\hline \multirow[t]{8}{*}{ Facilitators } & - Need a reason & 70 \\
\hline & - Ability to identify librarians & 26 \\
\hline & - Librarian accessibility & 25 \\
\hline & - Librarian approachability & 20 \\
\hline & - Increased awareness & 18 \\
\hline & - Library outreach & 11 \\
\hline & - Library instruction & 7 \\
\hline & - Decreased anxiety & 5 \\
\hline
\end{tabular}

Other students were candid in describing very specific barriers that prevented them from asking a librarian for help (see table 4). Responses encompassed several themes, including an inability to identify librarians $(\mathrm{n}=31)$. Students described a sense of confusion regarding where to locate librarians and how to differentiate librarians from other library personnel, as indicated by these undergraduate students' comments: "I' $m$ not sure if the people behind the circulation desk are librarians"; "Don't know where to find them or which ones could help"; and "I don't know how to tell who is a librarian and who isn't."

Library anxiety $(\mathrm{n}=25)$ was also an enduring theme that emerged from the data. Responses encapsulated students' feelings of discomfort, apprehension, and lack of confidence in approaching librarians. Some respondents attributed their anxiety to being new students, including these undergraduates: "I'm fairly new to the college experience and my cacious [sic] nature" and "I don't want to look 'new'." Additional students directly stated that their anxiety impacted their ability to ask for help. As one undergraduate stated, "I have a lot of anxiety and I don't want to ask the wrong person or ask a stupid question." An undergraduate student expressed feelings that they did not want "to look stupid for asking basic questions." Some students equated asking for help with being bothersome, as represented by this student's comment: "I feel uncomfortable and hate bothering people with stuff that I think I should know how to do."

Students also explained that their general lack of awareness $(n=15)$ about library resources and services often prevented them from asking a librarian for help. A graduate student commented, "Sometimes I am unaware of what resources are available from the library, so it doesn't occur to me to ask a librarian for assistance with those resources." Similar thoughts were echoed by an 
undergraduate student who stated, "I guess I'm not even really aware of what resources we have at the library so I wouldn't ask a librarian for help." Other students were unsure about the type of assistance that librarians could provide, as noted by this undergraduate: "Sometimes you aren't sure what they can and cannot help you with."

A small number of respondents indicated that librarian unapproachability $(\mathrm{n}=12)$ was a barrier to seeking help. One reason was that librarians appeared to be busy, as illustrated by the following undergraduate students' comments: "They look busy or not ready to help"; "They always look busy." Another undergraduate student described a hypothetical scenario that would prevent them from seeking help, with librarian unapproachability as a key factor: "I haven't experienced this, but if I were to pick something that would make me not want to ask for help would be if they seem to be too involved with a conversation with a coworker, or if they act like I am bothering them when I ask for help."

Inconvenience $(\mathrm{n}=12)$ was also described as a barrier to seeking help from librarians. Time and availability were common issues, as expressed by an undergraduate transfer student: "It seems like they are never there on the weekends, or at night! I'm usually in class or at work during the day, and it doesn't seem like anyone is there to ask when I'm there." Accessibility was another issue, as articulated by a graduate student who spent the majority of their time in another campus building: "They are at the library, I rarely leave the HH building."

Additionally, a small number of respondents avoided seeking help from librarians due to a lack of confidence in librarians' abilities $(n=5)$. Students were doubtful that librarians could assist them with their information needs, as expressed by these responses from undergraduate students: "I doubt they'd be able to do anything"; "Sometimes I might not ask for help because ...I don't think they can answer my question."

\section{Facilitators to Seeking Help from Librarians}

Ninety-seven percent $(n=227)$ of respondents answered this question: "What would make you more likely to ask for help from a librarian?" Some respondents reported that nothing (n =31) kept them from seeking a librarian's assistance, as expressed by this comment from an undergraduate student: "Literally nothing prevents me from asking for help." Additional themes also emerged from students' responses, indicating very specific facilitators that students felt would encourage them to seek a librarian's assistance (see table 4). Most students reported that they need a reason $(\mathrm{n}=70)$ to ask for help. An undergraduate noted that they would seek help if they desperately needed it: "Being desperate to find my material if I can not [sic] find it on my own."

Additional themes emerged that specifically addressed the role of librarians in increasing students' likelihood to ask for help. As noted previously, students described their inability to identify librarians as a barrier to seeking help. Accordingly, students also indicated the ability to identify librarians $(\mathrm{n}=26)$ as a key facilitator to seeking help. Issues surrounding librarian identification included a lack of clarity and recognition of who the librarians were, as noted by this graduate student: "If it was more clear who they were and what they could assist with." Students also described librarian accessibility $(\mathrm{n}=25)$ as a factor in making them more likely to seek help. Students offered recommendations regarding the visibility of librarians, including having an obvious presence in public areas where students would be most likely to need help, as noted by this undergraduate: "If they were in the area I needed help (specifically if I needed to find a book on the 4 th floor)." Librarian approachability $(\mathrm{n}=20)$ was also described as a factor 
in encouraging students to seek help. Students described preferred librarian characteristics, including "Friendliness" and a "Helping nature" as noted by two undergraduates.

In the previous section on barriers, students noted that their lack of awareness about library resources and services hindered their ability to seek help from librarians. In turn, students also expressed that an increased awareness $(n=18)$ of library resources and services would increase their likelihood to ask for help. Reasons largely included a better understanding of librarians' roles, duties, and expertise. A graduate student explained, "If I knew more about what they were capable of helping with, I would be more likely to ask for help." Another graduate student articulated that they would be more likely to ask for help if they knew that a librarian could best address their need: "If I needed help. Specifically if I know that it is something that I am aware that the librarian can help with." This undergraduate student noted that a familiarity with resources, as well as a better knowledge of librarians, would serve as key facilitators in asking for help more often: "I would probably ask librarians for help more if I a) knew what sort of texts/books we had available for use and b) which staff were 'librarians' or who I should ask to assist me in the library."

Students also described library outreach $(\mathrm{n}=11)$ as an effective mechanism that would encourage them to ask for help from librarians. Responses included descriptions of how librarians could actively and directly engage with students. Some students recommended that librarians could reach out to them by targeting those who need help, as illustrated by these comments from undergraduates: "Smiling, reaching out to me and asking if I need help"; "they could approach me"; "If they asked who needs help I'm sure more students would use it." Events and programming were described as specific modes of outreach, as expressed by a graduate student who stated, "Right to read week events like in elementary school but cooler and for college students" and by another graduate student who recommended "research days for each college."

Closely related to outreach, library instruction $(\mathrm{n}=7)$ also emerged as a theme among some students' responses, including formal classroom instruction and research consultations. A graduate student expressed that they might be more likely to ask a librarian for help "if I had a presentation in my college on the specific resources available to me in the library." An undergraduate student noted that it was beneficial: "Having the orientation class freshman year working with a librarian." One undergraduate transfer student pointed out the benefits of professors requiring students to consult with librarians: "I would also probably ask for help if my instructor told me to consult with a librarian. I can see how that would make them have crazy schedules, but I think I would feel more inclined afterwards to talk to a librarian."

Last, decreased anxiety ( $\mathrm{n}=5)$ was described as a factor in eliminating fear and hesitancy in approaching librarians for help. An undergraduate student explained that they would be more likely to ask for help "If I wasn't afraid to talk to people." Another undergraduate student cited newness as a factor, stating that "Some time to get use [sic] to college" was needed before they could ask a librarian for help. Another undergraduate described confidence as a factor, noting that "if I was just more self-confident" they might be more inclined to approach a librarian for assistance.

\section{Discussion}

The majority of respondents to this survey were 18 to 24 years of age, representative of the population known as Generation Z. Several key traits of this generation have been identified in the literature, including preferences to learn independently, favorability for face-to-face communication, and an inclination to seek help from peers. ${ }^{30}$ Findings from the present survey 
corresponded with several Generation Z traits in regard to students' help-seeking behaviors in the context of reference service utilization. The evidence from this survey indicates that students are regular library visitors with a vested interest in the library as a physical space. A very small percentage of students who responded to the survey had never visited a UT campus library. This study also found that, in general, students sought help for traditional reasons in traditional ways. Students' top three reasons for seeking reference assistance were to learn how to use a library resource, to find books, and to find articles.

When students did ask for help from a librarian, the majority did so in person. Yet, many also indicated that they preferred to consult with someone else before seeking a librarian's assistance. Students also indicated that they typically preferred to seek information on their own.

Indeed, students' perceived self-sufficiency was a recurring finding that appeared throughout this study. It was identified as a major reason that students did not seek help from librarians, as many preferred "to figure things out on [their] own." Qualitative results echoed this finding, wherein several students stated that they had no need to seek a librarian's assistance. Do these students legitimately have no need, or are they simply unaware of how a librarian can assist them? Survey results suggest that students might not fully understand the extent to which librarians can assist them with research. In the qualitative results, some students reported that their lack of awareness about library resources and services often prevented them from thinking about seeking a librarian's help in the first place. Quantitative findings revealed that, among overall respondents who had never asked for help, many of them had also never received library instruction.

These survey results suggest that lack of library instruction may adversely impact some students' likelihood to seek help from librarians. However, a relevant finding was also observed in relation to the impact of library instruction on students' frequency levels of seeking help. It was discovered that students who had received library instruction sought help from a librarian slightly less frequently than those who had not received instruction. One logical explanation is that students who have had library instruction may feel more empowered and confident to conduct research independently, not needing to consult a librarian as often. Based on these results, it is apparent that library instruction is impactful in at least two different ways. It can potentially equip students with the essential information literacy skills to be independent, self-sufficient researchers. This point has been reiterated in a study on undergraduates' helpseeking strategies. Students who received in-class library instruction felt that they had retained useful information to successfully complete research assignments. ${ }^{31}$ Library instruction may also increase students' awareness about the expertise of librarians, so that when they do need help with research, they will be more likely to ask. Further research is warranted in this area to more definitively evaluate the connection between library instruction and students' helpseeking behaviors, especially in regard to generational traits of traditional college students.

The importance of positive interactions with librarians has been cited as a potential factor in students' willingness to seek help from librarians. ${ }^{32}$ A successful liaison program can thus engender trust and break down barriers. This is evidenced by the frequency with which graduate survey respondents in academic programs with long-established library liaisons asked for help from a UT librarian. These graduate students generally receive library instruction in courses with advanced research components, and they are oftentimes required by their professor to consult with their respective liaison. Also, graduate students are required to complete a capstone project, thesis, or dissertation. As such, these students typically have 
rigorous information needs and long-term research goals that are commonly addressed in consultation with a subject librarian, including comprehensive literature searching and bibliographic citation management.

This study also confirmed that any initial contact between librarians and students is crucial. Results indicate that library instruction and professor encouragement to consult with a librarian both have an impact on students' views toward librarians. Students who had not received library instruction and were not required by their professor to consult with a librarian held low approachability ratings for librarians. This finding is reaffirmed in an exploratory study by Martin and Park wherein required reference consultations were shown to lessen students' anxiety and improve their views toward librarians' skills. ${ }^{33}$ It is significant to note that, despite societal emphasis placed on social media and online communication, meeting in person was preferred among survey respondents when seeking assistance from a librarian. This finding further underscores the importance of librarians being approachable, visible, and accessible to avoid confusion and not undermine the librarian's credibility as a resource. This approach may also improve students' identification of librarians and ease library anxiety, both of which continue to remain issues as revealed by the qualitative findings.

A number of students indicated that their anxiety made it difficult to speak with a librarian. Other students noted that, if they felt less anxious, they would be more likely to seek a librarian's help. Common observations were noted among survey respondents who described feelings of library anxiety. Several students felt that they would appear bothersome by asking a librarian for help. Others felt that they would look "stupid" or appear "new" by asking a librarian a question. These types of responses are indicators of shame, which has been identified by McAfee as an inherent contributing factor to patrons' library anxiety. McAfee suggests that further research on the "shame affect" may help to explain not only how it is manifested in library service transactions but also how it can be resolved. ${ }^{34}$

The last question on the survey ("Is there anything else you would like to tell us about reference services in the UT Libraries?") provided some additional insight into students' views, not only about reference services, but toward the UT Libraries in general. Responses to this question were not included as part of the formal data analysis of this study and were meant to provide general practical feedback to UT Libraries faculty and staff. However, the fact that students took the time to provide a mix of compliments, complaints, and recommendations is indicative of their vested interest in library services, resources, and physical facilities.

\section{Implications for Librarians}

Many of today's college students perceive themselves to be self-sufficient in seeking information, and for some this may be true, due in part to the beneficial impact of library instruction. Yet, other students who perceive themselves as self-sufficient, self-sustainable, and without any need to seek help may actually be unaware of the extent to which librarians can help them in facilitating the discovery of information. The preference to learn independently is common among Generation $\mathrm{Z}$, and librarians can do much to encourage independent lifelong learning through information literacy instruction. Still, a good number of students, also in this demographic, continually experience library anxiety that prevents them from seeking needed reference assistance from a librarian. The challenge for librarians is to effectively reach those students who have an information need but may not be willing to seek a librarian's help. Business and marketing professionals often emphasize the importance of knowing a client's needs, even 
before the client is aware of what they need themselves. This mindset has strong implications for library marketing to students, especially those who perceive themselves to be self-sufficient with no need to seek help. Targeted promotion of library resources and services may pique a student's curiosity by triggering an information need that they initially did not realize they had.

One way to achieve this is through library liaison programs, in which librarians become fully embedded in the curriculum and are in regular contact with students and faculty alike. Liaison programs can also build trust and rapport between librarians and students, potentially leading to a decrease in library anxiety and resulting in improved identification of librarians.

\section{Limitations}

The number of surveys analyzed $(n=235)$ represented 1 percent of the 20,648 students enrolled at UT during the time of the study. ${ }^{35}$ While findings may be transferrable to other academic library settings, this study was limited to one institution. A lack of diversity was present in survey respondents' demographic profile; therefore, the responses that were analyzed may reflect a narrow scope of student experiences, views, and perceptions. This study also used convenience sampling with self-selection; therefore, it lacked a probability sample. Self-selection bias, which is common in survey research, cannot be discounted in this study. The authors also noticed inconsistency with answers to question \#10 ("If you have asked a librarian for help, how did you interact with them?"). Some students $(n=31)$ who responded to this question had previously responded "Never" to question \#8 ("How often have you asked a librarian for help?"). The reason for this discrepancy is unclear. It is possible that respondents did not have a clear understanding of what it meant to ask a librarian for help in question \#8, even though terms were defined at the beginning of the survey. The answers offered for question \#10 may have reminded respondents of a previous help-seeking encounter with a librarian. Or perhaps the word "have" in question \#10 was elided, and the question was misunderstood as asking for a preferred method of contact.

\section{Conclusion}

The aim of this descriptive study was to answer questions about UT student characteristics, perceptions, and barriers and facilitators that might influence usage of library reference services. Age was revealed as a possible demographic characteristic related to students' use of reference services. The majority of respondents were 18 to 24 years of age. They described feelings of self-sufficiency in conducting research on their own, a common trait of Generation Z.

Another characteristic influencing students' use of library reference services was graduate student status. Survey results showed that graduate students in professional programs with long-established library liaisons were more likely to seek reference assistance. Also, experience with library instruction, or lack thereof, appeared to be a factor in students' frequency and likelihood of seeking help from a librarian. This study also suggests that student perceptions of librarians may be connected to usage or nonusage of reference services, including perceived approachability or unapproachability of librarians, lack of awareness about librarians' roles, and lack of confidence in librarians' abilities. The two most commonly reported barriers to reference service usage were an inability to identify librarians and library anxiety. Level of need was the top facilitator that determined students' likelihood to seek help from a librarian.

These findings provide insight into student usage and perceptions of reference services to inform local best practices at the UT Libraries. Data can potentially be applied to com- 
parable institutions in similar settings. As generational influences continue to impact the nature of students' help-seeking behaviors, it is key for librarians to adapt to users' changing needs, viewpoints, and preferences. However, as reference models and modes of information delivery continue to evolve to meet users' needs, certain enduring library values remain relevant. The importance of personalized liaison services, the easing of anxiety during the reference encounter, librarian identification and visibility, and librarians' instructional roles for information literacy are all core timeless values in academic libraries, regardless of patrons' generational characteristics.

\section{Acknowledgments}

The authors thank Dr. Brian Fink, Professor, College of Health and Human Services, The University of Toledo, for his instruction and guidance in using SPSS 24 software. The authors also thank library faculty colleagues who pretested the survey instrument and provided feedback on the manuscript. 


\section{APPENDIX. Survey of Student Usage and Perceptions of UT Libraries Reference Services}

Librarians at the University of Toledo Libraries are interested in seeing how students feel about and use reference services. For this survey, "reference" is defined as assistance with finding or locating information sources by library faculty or staff. The survey should take between 3 and 5 minutes to complete. It is anonymous; no one will be able to connect your responses back to you. The results of this survey will be used to improve reference services in the Libraries and may be reported in a presentation at a professional conference and/or published in an academic journal. The University of Toledo Social/Behavioral/Education Institutional Review Board has designated this study as exempt (IRB \# 201637). If you have questions about this research, contact john.napp@utoledo.edu. Thank you for taking time to complete this survey! 1. Age:

2. Gender:
18-24
$\square$ 25-34
$\square 35-44$
$\square 45-54$
$\square 55$ and over

$\square$ Female $\square$ Male $\square$ I prefer not to answer

3. What is your race/ethnicity? (select all that apply)

$\square$ African $\square$ Asian-American $\square$ Latino/Hispanic-American $\square$ Native American

$\square$ African-American $\square$ Caucasian $\square$ Middle Eastern $\square$ Mixed race/other

$\square$ Asian $\square$ Latino/Hispanic $\square$ Pacific Islander

4. Which of the following best describes your status at UT? (select all that apply)

$\square$ Undergraduate $\square$ Graduate $\square$ Distance learner $\square$ New student

$\square$ Internationalstudent $\square$ Transfer student $\square$ Military veteran

5. What college/school/program are you enrolled in?

6. Which library do you visit most often?

$\square$ Carlson (Main Campus) $\square$ Mulford (Health Science Campus)

$\square$ McMaster (Engineering) $\square$ LaValley (Law) $\square$ I have not visited the library

7. When visiting the library, can you tell which workers are librarians?

$\square$ Anyone behind the reference desk

- Anyone behind the circulation desk

$\square$ Only the people with library degrees are librarians

- I can't tell which library workers are librarians

$\square \quad$ I have not visited the library

8. How often have you asked a librarian for help?

$\square$ More than 5 times a semester $\square 2-5$ times a semester $\square$ Once a semester $\square$ Never

9. If never, why not? (select all that apply)

$\square \quad$ I did not think a librarian could help

- I did not want to bother the librarian

- I don't know how to find or contact a librarian

- I previously had a negative experience with a librarian

- I like to figure things out on my own

I would rather ask someone else for help (such as another student, graduate assistant, or professor)

I am not physically comfortable in the library

$\checkmark \quad$ Other (please specify): 
10. If you have asked a librarian for help, how did you interact with them? (select all thatapply)

$\square$ In person $\square$ Email $\square$ Chat/instant messaging $\square$ Telephone $\square$ Other (specify):

11. For which reason(s) have you asked a librarian for help? (select all that apply)

To get help finding books

$\square \quad$ To get help finding articles

$\square \quad$ To learn how to use a library resource (catalog, database, software, online book, or another resource)

$\square \quad$ To get help with citations/reference lists

$\square \quad$ I have not asked a librarian for help

$\square$ Other (please specify):

12. Has a librarian visited one of your classes to give instruction (such as using library resources, finding articles, doing research, and the like)?

$\square$ Yes $\square$ No $\square$ I don't remember

13. Were you ever required by your class instructor to consult with a librarian?

$\square$ Yes $\square$ No

14. Did you ask anyone for help before you spoke with a librarian?

$\square \quad$ Friend

$\square$ Student from my class

$\square \quad$ Family member

$\square$ Professor/instructor

$\square \quad$ Other (please specify):

15. What makes it difficult for you to ask a librarian for help?

16. What would make you more likely to ask for help from a librarian?

17. In general, how would you rate the approachability of librarians at UT (online or in person)?

$\square$ Very approachable

$\square$ Approachable

$\square \quad$ Slightly approachable

$\square$ Not at all approachable

18. Is there anything else you would like to tell us about reference services in the UTLibraries?

\section{Notes} 74-81.

1. Samuel S. Green, "Personal Relations between Librarians and Readers," American Library Journal 1 (1876):

2. Firouzeh F. Logan, “A Brief History of Reference Assessment: No Easy Solutions," Reference Librarian 50, no. 3 (2009): 225-33.

3. Peter Hernon and Maureen Pastine, "Student Perceptions of Academic Librarians," College E Research Libraries 38, no. 2 (1977): 129-39.

4. Marjorie E. Murfin and Gary M. Gugelchuk, "Development and Testing of a Reference Transaction Assessment Instrument," College \& Research Libraries 48, no. 4 (1987): 314-38; Emily L. Rimland, "Do We Do It Good Well? A Bibliographic Essay on the Evaluation of Reference Effectiveness," Reference Librarian 47, no. 2 (2007): $41-55$.

5. Nancy Courtney, "Evaluating the Use of Paraprofessionals at the Reference Desk," College E Undergraduate Libraries 8, no. 1 (2001): 31-40; Kirstin Dougan, "Delivering and Assessing Music Reference Services," Reference Librarian 54, no. 1 (2013): 38-54; Eric Novotny and Emily Rimland, "Using the Wisconsin-Ohio Reference Evaluation Program (WOREP) to Improve Training and Reference Services," Journal of Academic Librarianship 33, no. 3 (2007): 382-92. 
6. Constance A. Mellon, “Library Anxiety: A Grounded Theory and Its Development," College E Research Libraries 47, no. 2 (1986): 160-65.

7. Sharon L. Bostick, "The Development and Validation of the Library Anxiety Scale" (PhD diss., Wayne State University, 1992).

8. Heather Carlile, "The Implications of Library Anxiety for Academic Reference Services: A Review of the Literature," Australian Academic \& Research Libraries 38, no. 2 (2007): 129-47.

9. Pamela N. Martin and Lezlie Park, "Reference Desk Consultation Assignment: An Exploratory Study of Students' Perceptions of Reference Service," Reference \& User Services Quarterly 49, no. 4 (2010): 333-40.

10. Qun G. Jiao, Anthony J. Onwuegbuzie, and Arthur A. Lichtenstein, "Library Anxiety: Characteristics of 'at-Risk' College Students," Library \& Information Science Research 18, no. 2 (1996): 151-63; Jessica Platt and Tyson L. Platt, "Library Anxiety among Undergraduates Enrolled in a Research Methods in Psychology Course," Behavioral \& Social Sciences Librarian 32, no. 4 (2013): 240-51.

11. Carlile, "The Implications of Library Anxiety for Academic Reference Services."

12. Anne M. Cooper and Kimberly A. Wells, "Connecting 24/5 to Millennials: Providing Academic Support Services from a Learning Commons," Journal of Academic Librarianship 35, no. 1 (2009):78.

13. Jennifer L. Bonnet and Benjamin McAlexander, "Structural Diversity in Academic Libraries: A Study of Librarian Approachability," Journal of Academic Librarianship 38, no. 5 (2012):277-86.

14. Marynelle DeVore-Chew, Brian Roberts, and Nathan M. Smith, "The Effects of Reference Librarians' Nonverbal Communications on the Patrons' Perceptions of the Library, Librarians, and Themselves," Library $\mathcal{E}$ Information Science Research 10 (1988): 389-400.

15. Marie L. Radford, "Approach or Avoidance? The Role of Nonverbal Communication in the Academic Library User's Decision to Initiate a Reference Encounter," Library Trends 46, no. 4 (1998): 699-717.

16. Bonnet and McAlexander, "Structural Diversity in Academic Libraries."

17. Lizah Ismail, "Closing the Gap: Determining the Library Help-Seeking Preferences of Adult Learners in a Graduate Social Work Program," Reference \& User Services Quarterly 53, no. 2 (2013): 164-73.

18. Susan Gardner and Susanna Eng, "What Students Want: Generation $Y$ and the Changing Function of the Academic Library," portal: Libraries and the Academy 5, no. 3 (2005): 405-20.

19. Corey Seemiller and Meghan Grace, Generation Z Goes to College (San Francisco: Jossey-Bass, 2016).

20. Jingzhen Xie and Lili Sun, "Exploring Chinese Students' Perspective on Reference Services at Chinese Academic Libraries: A Case Study Approach," Journal of Academic Librarianship 41, no. 3 (2015): 228-35.

21. Steve Black and Ross Krawczyk, "Brief Intervention to Change Students' Attitudes Regarding Library Research," Reference \& User Services Quarterly 56, no. 4 (2017): 277-84.

22. Andrew Brenza, Michelle Kowalsky, and Denise Brush, "Perceptions of Students Working as Library Reference Assistants at a University Library," Reference Services Review 43, no. 4 (2015):722-36.

23. Gardner and Eng, "What Students Want."

24. Rachel Bickley and Sheila Corrall, "Student Perceptions of Staff in the Information Commons: A Survey at the University of Sheffield," Reference Services Review 39, no. 2 (2011):223-43.

25. Jody Fagan, “Students' Perceptions of Academic Librarians," Reference Librarian 37, no. 78 (2003): 131-48.

26. Jason Coleman, Melissa N. Mallon, and Leo Lo, "Recent Changes to Reference Services in Academic Libraries and Their Relationship to Perceived Quality: Results of a National Survey," Journal of Library Administration 56, no. 6 (2016): 673-96.

27. Bruce Harley, Megan Dreger, and Patricia Knobloch, "The Postmodern Condition: Students, the Web, and Academic Library Services," Reference Services Review 29, no. 1 (2001): 23-32.

28. Graham R. Gibbs, "Thematic Coding and Categorizing" in Analyzing Qualitative Data (Los Angeles: SAGE, 2007), 38-55.

29. Porcia Vaughn and Cherie Turner, "Decoding via Coding: Analyzing Qualitative Text Data through Thematic Coding and Survey Methodologies," Journal of Library Administration 56, no. 1 (2016): 41-51.

30. Seemiller and Grace, Generation Z Goes to College.

31. Molly Beisler and Ann Medaille, "How Do Students Get Help with Research Assignments? Using Drawings to Understand Students' Help Seeking Behavior," Journal of Academic Librarianship 42, no. 4 (2016): 390-400.

32. Susan Miller and Nancy Murillo, “Why Don't Students Ask Librarians for Help? Undergraduate HelpSeeking Behavior in Three Academic Libraries," in College Libraries and Student Culture: What We Now Know, eds. Lynda M. Duke and Andrew D. Asher (Chicago: American Library Association, 2012), 50-65.

33. Martin and Park, "Reference Desk Consultation Assignment."

34. Erin L. McAfee, "Shame: The Emotional Basis of Library Anxiety," College \& Research Libraries 79, no. 2 (2018): 237-56.

35. The University of Toledo Office of Institutional Research, The University of Toledo 2016 Facts at a Glance, available online at http://oir.utoledo.edu/Facts/Fall\%202016.pdf [accessed 1 April 2018]. 